\title{
Perbandingan Model Pembelajaran Problem Solving dan Problem Posing Terhadap Kemampuan Berpikir Kritis Matematika Siswa Kelas V Sekolah Dasar
}

\author{
Prita Tiya Pramesti ${ }^{1}$, Eunice Widyanti Setyaningtyas ${ }^{2}$ \\ ${ }^{1,2}$ Program Studi Pendidikan Guru Sekolah Dasar, Fakultas Keguruan Ilmu Pendidikan, Universitas Kristen Satya Wacana, \\ Jl. Diponegoro No 52-60, Jawa Tengah, Indonesia \\ pritatiya661@gmail.com
}

\begin{abstract}
This study aims to see the effectiveness of the learning model Problem Solving and Problem Posing seen from the students' critical thinking abilities. The subjects of this study were 58 th grade students in Legoksari elementary school and in Pagersari elementary school. The techniques used to collect data used observation and tests. This study uses Problem Solving and Problem Posing instruments and uses critical thinking skills instruments. The data analysis used was quantitative description analysis as a conditional test, T test, and N-Gain. The results of hypothesis testing, with the t-sig (2-tailed) test obtained $0.000<0.05$ with tcount 5.081> ttable 2.002 , then $\mathrm{H} 0$ is rejected, which means that there is a difference in the ability to think critically in mathematics. This is evidenced by the increase in the critical thinking skills of grade 5 students using the model Problem Posing with an average initial score of 72.73 increasing to 80.67. In addition, the increase in critical thinking skills of grade 5 students using the model Problem Solving, the initial score obtained, namely 67.96, increased to 74.75. This shows that is Problem Posing more effective than Problem Solving seen from the ability to think critically in mathematics.
\end{abstract}

Keywords: Problem Posing, Problem Solving, Critical Thinking Ability

Abstrak
Penelitian ini dilakukan dengan tujuan untuk melihat efektivitas model pembelajaran Problem Solving dan Problem Posing dilihat dari kemampuan berpikir kritis siswa kelas 5 SD. Subjek dari penelitian ini adalah siswa kelas 5 di SD Negeri Legoksari dengan jumlah 30 siswa dan SD Negeri 02 Pagersari dengan jumlah 24 siswa. Teknik yang digunakan untuk mengumpulakan data ialah menggunakan observasi dan tes. Penelitian ini mengggunakan instrumen RPP Problem Solving dan Problem Posing serta menggunakan instrumen kemampuan berpikir kritis siswa. Analisis data yang digunakan adalah analisis deksripsi kuantitatif sebagai uji persyarat, uji $\mathrm{T}$, dan N-Gain. Hasil pengujian hipotesis, dengan uji t-sig (2-tailed) diperoleh 0,000 <0,05 dengan thitung 5,081> ttabel 2,002 maka H0 ditolak yang memiliki arti bahwa terdapat perbedaan kemampuan berpikir kritis matematika. Hal tersebut dapat dibuktikan dengan meningkatnya kemampuan berpikir kritis siswa kelas 5 di SD Negeri Legoksari menggunakan model Problem Posing dengan rata-rata perolehan skor awal 72,73 meningkat menjadi 80,67. Selain itu, meningkatnya kemampuan berpikir kritis siswa kelas 5 di SD Negeri 02 Pagersari menggunakan model Problem Solving rata-rata perolehan skor awal yaitu 67,96 meningkat menjadi 74,75. Hal ini menunjukan bahwa model Problem Posing lebih efektif dibandingkan dengan model Problem Solving dilihat dari kemampuan berpikir kritis matematika.

Kata kunci: Problem Posing, Problem Solving, Berpikir Kritis Matematika

Copyright (c) 2021 Prita Tiya Pramesti, Eunice Widyanti Setyaningtyas

Corresponding author: Prita Tiya Pramesti

Email Address: pritatiya661@gmail.com (Jl. Diponegoro No 52-60, Jawa Tengah, Indonesia)

Received 15 April 2021, Accepted 17 April 2021, Published 17 April 2021

\section{PENDAHULUAN}

Belajar merupakan tuntutan yang harus dilakukan oleh seorang pelajar. Pembelajaran yang baik, harus dikemas sebaik mungkin supaya siswa dapat memahami ilmu pengetahuan termasuk ilmu pengetahuan dalam bidang matematika. Dalam rangka meningkatkan mutu pendidikan sekolah, upaya yang dilakukan pemerintah adalah melakukan perbaikan proses belajar mengajar yang berkualitas. Seperti yang sudah tercantum dalam Peratutan Menteri Pendidikan Nasional No 41 Tahun 2007 tentang standar proses, bahwa pembelajaran pada suatu pendidikan merupkan proses yang harus dilaksanakan 
dengan interaktif, inspiratif, menantang, menyenangkan, momotivasi siswa untuk berpartisipasi secara lebih aktif, serta dapat memberikan ruang bagi prakarsa, kreativitas, kemandirian sesuai dengan bakat dan minat serta sesuai dengan perkembang fisik dan psikologi dari siswa. Dalam menyelenggarakan pembelajaran harus disesuaikan dengan kurikulum yang berlaku. Menurut Permendikbud No 20 Tahun 2003 disebutkan bahwa kurikulum merupakan seperangkat perencanaan dan sebuah pengaturan yang dijadikan sebagai pedoman untuk mencapai tujuan pendidikan nasional yang berkaitan dengan tujuan, isi, bahan ajar dan cara yang dapat digunakan dalam mencapai tujuan pendidikan yang akan dicapai (Kemendikbud, 2003). Sampai saat ini kurikulum pembelajaran yang digunakan di Indonesia telah mengalami beberapa kali perubahan baik perbaikan maupun penyempurnaan, sehingga saat ini diterapkan Kurikulum 2013 yang dirasa mampu untuk menghadapi tuntutan kehidupan dan perkembangan zaman pada abad 21.

Kurikulum 2013 siswa menuntut siswa untuk terlibat secara lebih aktif, kreatif, dan inovatif dalam menghadapi setiap permasalahan. Oleh karena itu, penggunaan model pembelajaran berbasis masalah dirasa cukup mampu dalam membantu siswa untuk menggali informasi berdasarkan pengalaman dan berorientasi pada masalah. Menurut (Sanjaya, 2018) dalam belajar memecahkan suatu masalah, siswa dapat dihadapkan pada suatu masalah yang pada akhirnya nanti mereka tidak hanya belajar memecahkan masalah tetapi juga mendapatkan pembelajaran mengenai hal baru. Model pembelajaran berbasis masalah yang dapat diterapkan adalah Problem Solving dan Problem Posing. Menurut:(Djamarah, S. B., \& Zain, 1997) Problem Solving bukan hanya sekedar model untuk mengajar tetapi juga disebut sebagai suatu model untuk berpikir, karena dalam prosesnya diawali dengan mencari data sampai dengan akhirnya dapat menarik kesimpulan. Menurut (Widiawati, Subandi, \& Fajaroh, 2016) Problem Solving merupakan sebuah perilaku yang diarahkan untuk mencapai suatu tujuan yang membutuhkan kemampuan berpikir untuk mendeskripsikan masalah dan membutuhkan sejumlah metode atau strategi untuk memecahkan masalah yang dihadapi. Berdasarkan pengertian kedua model dapat dilihat bahwa keduanya mampu mengasah pemikiran siswa berpikir lebih kritis. Untuk dapat meningkatkan pemikiran kritis pada siswa, maka dapat dilakukan dengan pemberian permasalahan. Permasalahan yang diberikan yakni permasalahan yang berhubungan dengan kehidupan sehari-hari, seperti pada pembelajaran matematika pada materi statistik yang biasanya hanya diselesaikan menggunakan rumus tanpa mengetahui konsepnya terlebih dahulu.

Kegiatan berpikir kritis menurut Costa (2009) dalam (Ardiyanti, 2016) di dalamnya meliputi mengobservasi dan mengumpulkan data, memformulasikan dan menguji hipotesis, dan yang terakhir adalah mengajukan pertanyaan. Sejalan dengan hal tersebut (Fachrurazi, 2011) juga mengatakan bahwa berpikir kritis merupakan sebuah proses sistematis yang memberikan ruang kepada siswa untuk merumuskan dan mengevaluasi keyakinan dan pendapat dari mereka sendiri. Dalam tingkatannya berpikir kritis dapat diklasifikasikan menjadi empat tingkatan, yang pertama yaitu menghafal yang dilakukan secara rutin, mengulang kembali informasi, dalam menanggapi hal baru diperlukan sikap yang kritis, serta kreatif dalam pola berpikir. Kemampuan berpikir kritis dalam pembelajaran di jenjang 
Perbandingan Model Pembelajaran Problem Solving dan Problem Posing Terhadap Kemampuan Berpikir Kritis Matematika Siswa Kelas V Sekolah Dasar, Prita Tiya Pramesti, Eunice Widyanti Setyaningtyas

Sekolah Dasar dirasa masih perlu untuk dikembangkan, rendahnya kemampuan berpikir kritis pada siswa dapat disebabkan oleh beberapa faktor. Salah satu diantaranya adalah lemahnya proses pembelajaran, karena aspek mekanistik lebih ditekankan pada siswa sedangkan kemampuan berpikir kritisnya diabaikan. Berpikir kritis juga dapat diartikan sebagai kemampuan menganalisis dari suatu permasalahan. Oleh karena itu, dalam pembelajaran matematika kemampuan berpikir kritis pada siswa dianggap sangat penting. Karena dengan berpikir kritis siswa akan berusaha menemukan permasalahan dan cara penyelesaiannya dengan tepat.

Penelitian yang sebelumnya telah dilakukan penelitian yang dilakukan oleh (Nugraha \& Mahmudi, 2015) menunjukkan bahwa metode pembelajaran berbasis masalah Problem Posing lebih unggul dibandingkan dengan pembelajaran konvensioanl, siswa yang diberikan pembelajaran dengan menggunakan model Problem Posing memberikan hasil yang lebih baik dibandingkan dengan siswa yang diberikan pembelajaran menggunakan pembelajaran konvensional. Penelitian yang sama juga dilakukan oleh (Kurniawan, 2016) dapat disimpulkan bahwa keterampilan berpikir kritis matematis dengan menggunakan pembelajaran Problem Solving menunjukkan hasil yang lebih baik daripada keterampilan berpikir kritis yang dilakukan dengan menggunakan pembelajaran tradisional. Rifaatul Mazmuzah (2015) juga melakukan penelitian yang menunjukkan hasil bahwa peningkatan kemampuan berpikir kritis siswa dengan menggunakan pendekatan Problem Posing lebih baik dari pada siswa yang mendapatkan pembelajaran menggunakan pembelajaran konvensional. Penelitian yang sama juga dilakukan oleh (Titin Sri Wartini1, Rita Retnowati2, 2018) menunjukkan bahwa model pembelajaran Problem Solving dan Problem Posing dapat meningkatkan kemampuan berpikir kritis siswa. Hal ini dapat dilihat dari hasil pratest dan posttest yang mengalami peningkatan . Penelitian lain juga dilakukan oleh (Sarimanah, 2017) yang menunjukkan bahwa hasil N-gain kelas eksperimen lebih tinggi daripada kelas kontrol. Oleh karena itu, tujuan dilakukannya penelitian ini adalah untuk menguji ada atau tidaknya perbedaan efektivas model pembelajaran Problem Solving dan Problem Posing terhadap kemampuan berpikir kritis matematika siswa kelas V di sekolah dasar.

\section{METODE}

Jenis penelitian yang digunakan adalah penelitian eksperimen. Penelitian eksperimen adalah jenis penelitian yang menggunakan kelas kontrol dan kelas eksperimen. Penelitian ini dilakukan untuk mengetahui pengaruh perlakuan terhadap kemampuan berpikir kritisi matematis siswa. Cara yang digunakan untuk mengetahuinya adalah dengan membandingkan kemampuan berpikir kritis matematis siswa antara kelompok eksperimen dengan kelompok kontrol. Desain penelitian yang digunakan adalah jenis penelitian sebenarnya (True Eksperimental Design) dengan pola The Pretest-Postest Control Group Design. Ciri utama dari true experimental adalah sampel yang digunakan untuk eksperimen maupun sebagai kelompok kontrol diambil secara random dari populasi tertentu. Jadi cirinya adalah adanya kelompok kontrol dan sampel yang dipilih secara random (Sugiyono, 2011). Desain penelitian ini diawali dengan satu kali kegatan pratest ysng dilakukan pada dua klompok kelas. Model 
pembelajaran Problem Solving digunakan untuk kelas kontrol dan model pembelajaran Problem Posing akan digunakan untuk kelas eksperimen. Untuk tahap selanjutnya, kedua kelas akan diberikan posttest. Menurut (Sugiyono, 2011) gambaran dasar mengenai desain penelitian The Pretest-Postest Control Group Design sebagai berikut.

Tabel 1. Desain penelitian The Pretest-Postest Control Group Design

Keterangan:

\begin{tabular}{|l|l|l|}
\hline $\mathrm{O} 1$ & $\mathrm{X} 1$ & $\mathrm{O} 2$ \\
\hline $\mathrm{O} 1$ & $\mathrm{X} 2$ & $\mathrm{O} 2$ \\
\hline
\end{tabular}

O1: Pratest kelas eksperimen

O1: Posttest kelas eksperimen

X1: Model Pembelajaran Problem Posing untuk kelas eksperimen

X2: Model Pembelajaran Problem Solving untuk kelas kontrol

O2: Pratest kelas kontrol

O2: Posttest kelas kontrol

Adapun tempat pelaksanaan penelitian ini adalah di SD Negeri Legoksari dan SD Negeri 02 Pagersari Kecamatan Tlogomulyo, Kabupaten Temanggung. Pengambilan sampel dalam penelitian ini diperoleh dengan menggunakan teknik probability sampling jenis cluster sampling. Sehungga sampel yang terpilih sebagai tempat pelaksanaan penelitian ini adalah di SD Negeri Legoksari sebagai kelas eksperimen dan SD Negeri 02 Pagersari sebagai kelas kontrol. Penelitian ini dilaksanakan pada semester 2 tahun ajaran 2020/2021. Subjek dalam penelitian ini adalah 58 siswa. 30 siswa dari SD Negeri Legoksari dan 28 siswa dari SD Negeri 02 Pagersari. Instrumen yang digunakan dalam penelitian ini adalah intrumen tes yang terdiri dari soal pratest dan posttest. Untuk menentukan butir soal instrumen tersebut layak diberikan kepada kelompok sampel, maka terlebih dahulu dilakukan uji coba. Uji coba tersebut meliputi: uji validitas dan uji reliabilitas. Berikut ini merupakan hasil uji validitas dan reliabiltas

Tabel 2. Uji Validitas menggunakan SPSS 25 for Windows

\begin{tabular}{|c|c|c|c|}
\hline \multicolumn{2}{|c|}{} & $\mathrm{N}$ & $\%$ \\
\hline Cases & Valid & 30 & 100.0 \\
\cline { 2 - 4 } & Excluded $^{\mathrm{a}}$ & 0 & 0.0 \\
\cline { 2 - 4 } & Total & 30 & 100.0 \\
\hline
\end{tabular}

Dari tabel di atas dapat dinyatakan bahwa uji validitas dari 10 soal yang diujikan kepada 30 siswa mendapatkan hasil total 100.0 yang dapat dinyatakan valid.

Tabel 3. Statistik Reliabilitas

\begin{tabular}{|c|c|}
\hline Cronbach's Alpha & N of Items \\
\hline 0.931 & 10 \\
\hline
\end{tabular}

Berdasarkan hasil statistik reliabilitas di atas maka dapat dikatakan sangat reliable. Tingkat 
Perbandingan Model Pembelajaran Problem Solving dan Problem Posing Terhadap Kemampuan Berpikir Kritis Matematika Siswa Kelas V Sekolah Dasar, Prita Tiya Pramesti, Eunice Widyanti Setyaningtyas

reliabilitas dengan metode Alpha Crobach jika diukur berdasarkan skala alpha 0 sampai dengan 1 maka akan mendapatkan hasil sebagai berikut (Budi: 2006)

$0,00-0,200 \quad$ : kurang reliabel

$0,201-0,400 \quad$ agak reliabel

$0,401-0,600 \quad$ : cukup reliabel

$0,601-0,800 \quad$ : reliabel

$0,801-1,000 \quad$ : sangat reliable

Analisis data dalam penelitian ini menggunakan analisis data deskriptif sebagai uji prasyarat yang meliputi uji normalitas data dan uji homogenitas. Uji prasyarat dilakukan sebelum melakukan uji beda (t) yang menggunakan analisis independent sample $\mathrm{T}$ test dengan kriteria $\mathrm{H} 0$ ditolak jika thitung $>$ ttabel tujuannya adalah untuk mengetahui ada tidaknya perbedaan perolehan rata-rata dari kelompok eksperimen maupun kelompok kontrol. Selain menggunakan uji beda (t) juga menggunakan uji N-Gain yang bertujuan untuk membandingkan model manakah yang lebih efektif untuk meningkatkan kemampuan berpikir kritis matematika siswa kelas 5 .

\section{HASIL DAN DISKUSI}

\section{Analisis deskriptif}

Hasil penelitian ini menunjukkan bahwa terdapat perbedaan yang cukup signifikan antara kelas kontrol dan kelas eksperimen. perbedaan tersebut dapat dilihat dari analisis deskriptif berdasarkan skor hasil setelah diberikan perlakuan baik pada kelas eksperimen maupun kelas kontrol. Kemudian disajikan dalam tabel deskriptif statistik yang memuat nilai minimal diolah menggunakan SPSS 25 for Windows. Tujuan dari analisis deskriptif sendiri adalah untuk mengetahui perbedaan hasil belajar siswa dari kelas eksperimen dan kelas kontrol. Data yang disajikan berupa data hasil belajar sebelum diberikan perlakuan (prates) untuk mengetahui kemampuan awal berpikir kritis matematika siswa. setelah itu didapatkan hasil belajar setelah mendapatkan perlakuan (posttest). Hasil analisis statistic deskriptif data penelitian ini dapat dilihat pada tabel 4 .

Tabel 4. Statistik Deskriptif Kelas Eksperimen

\begin{tabular}{|c|c|c|c|c|c|}
\hline & N & Minimum & Maximum & Mean & Std. Deviation \\
\hline Pratest Eksperimen & 30 & 57 & 80 & 72.73 & 6.389 \\
\hline Posttest EKsperimen & 30 & 71 & 88 & 80.67 & 4.513 \\
\hline Valid N (listwise) & 30 & & & & \\
\hline
\end{tabular}

Berdasarkan data yang disajikan pada tabel di atas diketahui bahwa nilai rata-rata prates kelas eksperimen sebelum diberikan perlakukan dengan model Problem Posing adalah 72,73 dengan standar deviasi 6,389. Setelah diberikan perlakuan dengan menggunakan model Problem Posing nilai rataratanya meningkat menjadi 80.67. Perolehan nilai tertinggi sebelum diberikan perlakuan model Problem Posing adalah 80 dan nilai terendah 57 namun, setelah diberikan perlakuan model Problem Posing nilai tertinggi adalah 88 dan nilai terendah 71 . Selain data hasil belajar kelas eksperimen, data hasil belajar 
kelas kontrol dapat dilihat pada tabel 3 di bawah ini:

Tabel 5. Statistik Deskriptif Kelas Kontrol

\begin{tabular}{|l|c|c|c|c|c|}
\hline & N & Minimum & Maximum & Mean & Std. Deviation \\
\hline Prates Kontrol & 28 & 53 & 76 & 67.96 & 7.371 \\
\hline Posttest Kontrol & 28 & 68 & 83 & 74.75 & 4.343 \\
\hline Valid N (listwise) & 28 & & & & \\
\hline
\end{tabular}

Berdasarkan data yang disajikan pada tabel di atas diketahui bahwa nilai rata-rata prates kelas kontrol sebelum diberikan perlakukan dengan model Problem Solving adalah 67,96 dengan standar deviasi 7,371. Setelah diberikan perlakuan dengan menggunakan model Problem Solving nilai rataratanya meningkat menjadi 74,75. Perolehan nilai tertinggi sebelum diberikan perlakuan model Problem Solving adalah 76 dan nilai terendah 53 namun, setelah diberikan perlakuan model Problem Posing nilai tertinggi adalah 83 dan nilai terendah 68 .

Deskripsi komparasi dalam penelitian ini adalah untuk membandingkan kemampuan berpikir kritis siswa dalam prates dan posttest antara kelompok eksperimen dan kelompok kontrol. Berikut merupakan tabel komparasi hasil pengukuran kemampuan berpikir kritis siswa :

Tabel 6. Komparasi Hasil Pengukuran Kemampuan Berpikir Kritis Siswa

\begin{tabular}{|l|c|c|c|}
\hline \multicolumn{4}{|c|}{ Komparasi Hasil Pengukuran Kemampuan Berpikir Kritis } \\
\hline \multirow{2}{*}{ Pengukuran } & \multicolumn{2}{|c|}{ Rata-rata Skor (Mean) } & \multirow{2}{*}{ Selisih } \\
\cline { 2 - 3 } & Eksperimen & Kontrol & 4.77 \\
\hline Prates & 72.73 & 67.96 & 5.91 \\
\hline Posttest & 80.66 & 74.75 & \\
\hline
\end{tabular}

Berdasarkan hasil data komparasi rata-rata tabel di atas, rata-rata skor pra tes antara kedua kelompok yaitu kelompok eksperimen yang diberikan perlakuan dengan menggunakan model pembelajaran Problem Posing dan kelompok kontrol yang diberikan perlakuan dengan menggunakan model pembelajaran Problem Solving memiliki selisih 4,77. Sedangkan untuk rata-rata skor posttest antara kelompok yang diberikan perlakuan dengan menggunakan model pembelajaran Problem Posing dan kelompok kontrol yang diberikan perlakuan dengan menggunakan model pembelajaran Problem Solving memiliki selisih 5,91. Di bawah ini merupakan diagram komparasi antara kedua kelompok.

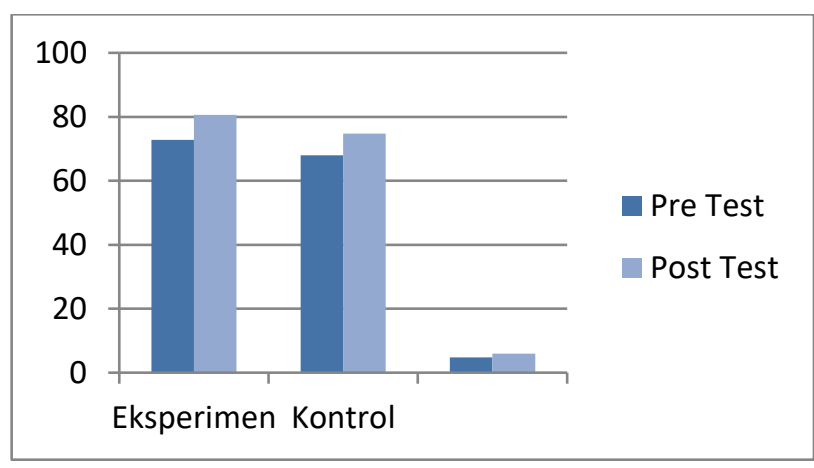

Gambar 1. Komparasi Hasil Pengukuran 
Perbandingan Model Pembelajaran Problem Solving dan Problem Posing Terhadap Kemampuan Berpikir Kritis Matematika Siswa Kelas V Sekolah Dasar, Prita Tiya Pramesti, Eunice Widyanti Setyaningtyas

Berdasarkan gambar diagram di atas dapat diketahui bahwa adanya peningkatan pada kedua kelompok baik kelompok eksperimen yang diberikan perlakuan dengan menggunakan model pembelajaran Problem Posing maupun kelompok kontrol yang diberikan perlakuan dengan menggunakan model pembelajaran Problem Solving.

\section{Analisis data}

Penelitian ini menggunakan uji normalitas dengan menggunakan SPSS 25 for Windows. Tujuan dari dilakukannya uji normalitas adalah untuk mengetahui penyebaran data dari kelompok eksperimen dan kelompok kontrol yang berdistribusi normal atau tidak. berikut merupakan tabel hasil uji normalitas:

Tabel 7. Data Hasil Uji Normalitas

\begin{tabular}{|l|l|c|c|c|c|c|c|}
\hline \multicolumn{2}{|c|}{ Kelas } & \multicolumn{2}{|c|}{ Kolmogorov-Smirnov } & \multicolumn{3}{|c|}{ Shapiro-Wilk } \\
\cline { 3 - 9 } & Statistic & Df & Sig. & Statistic & Df & Sig. \\
\hline \multirow{3}{*}{$\begin{array}{l}\text { Kemampuan } \\
\text { Berpikir Kritis }\end{array}$} & $\begin{array}{l}\text { Prates Eksperimen } \\
\text { Problem Posing }\end{array}$ & 0.134 & 30 & 0.178 & 0.932 & 30 & 0.055 \\
\cline { 2 - 9 } & $\begin{array}{l}\text { Prates Kontrol Problem } \\
\text { Solving }\end{array}$ & 0.168 & 28 & 0.043 & 0.943 & 28 & 0.133 \\
\cline { 2 - 9 } & $\begin{array}{l}\text { Posttest Eksperimen } \\
\text { Problem Posing }\end{array}$ & 0.115 & 30 & $.200^{*}$ & 0.961 & 30 & 0.336 \\
\cline { 2 - 8 } & $\begin{array}{l}\text { Posttest Kontrol } \\
\text { Problem Solving }\end{array}$ & 0.140 & 28 & 0.170 & 0.950 & 28 & 0.199 \\
\hline
\end{tabular}

1. Tingkat signifikansi nilai prates kelas eksperimen dengan model Problem Posing adalah 0,055 > 0,05 maka dapat diartikan berdistribusi normal.

2. Tingkat signifikansi nilai posttest kelas eksperimen dengan model Problem Posing adalah 0,336 > 0,05 maka dapat diartikan berdistribusi normal.

3. Tingkat signifikansi nilai prates kelas kontrol dengan model Problem Solving adalah 0,133>0,05 maka dapat diartikan berdistribusi normal.

4. Tingkat signifikansi nilai prates kelas kontrol dengan model Problem Solving adalah 0,199>0,05 maka dapat diartikan berdistribusi normal.

Tabel 8. Uji Homogenitas Sebelum Perlakuan

\begin{tabular}{|c|c|c|c|c|c|}
\hline & & Levene Statistic & df1 & $\mathrm{df} 2$ & Sig. \\
\hline \multirow{4}{*}{$\begin{array}{l}\text { Kemampuan } \\
\text { Berpikir Kritis }\end{array}$} & Based on Mean & 1.469 & 1 & 56 & 0.231 \\
\hline & Based on Median & 1.417 & 1 & 56 & 0.239 \\
\hline & $\begin{array}{l}\text { Based on Median and with } \\
\text { adjusted df }\end{array}$ & 1.417 & 1 & 44.256 & 0.240 \\
\hline & Based on trimmed mean & 1.431 & 1 & 56 & 0.237 \\
\hline
\end{tabular}

Selain menggunakan uji normalitas, juga digunakan uji homogenitas yang terdapat pad tabel di atas dan diperoleh hasil uji homogenitas menggunakan metode Levene's Test dimana memilih satu interpretasi statistik yang berdasarkan pada rata-rata (Based on Mean). Berdasarkan tabel menunjukkan bahwa hasil uji homogenitas sebelum dilakukan perlakuan memperoleh signifikansi 0,231 dimana > 0,05 maka dapat diartikan bahwa kelompok eksperimen dan kelompok kontrol memiliki varian yang sama atau dapat dikatakan homogen. 
Tabel 9. Uji Homogenitas Setelah Perlakuan

\begin{tabular}{|l|l|c|c|c|c|}
\hline \multicolumn{2}{|c|}{} & $\begin{array}{c}\text { Levene } \\
\text { Statistic }\end{array}$ & df1 & df2 & Sig. \\
\hline \multirow{2}{*}{$\begin{array}{l}\text { Kemampuam } \\
\text { Berpikir } \\
\text { Kritis }\end{array}$} & Based on Mean & 0.033 & 1 & 56 & 0.856 \\
\cline { 2 - 6 } & Based on Median & 0.088 & 1 & 56 & 0.768 \\
\cline { 2 - 6 } & Based on Median and with adjusted df & 0.088 & 1 & 55.945 & 0.768 \\
\cline { 2 - 6 } & Based on trimmed mean & 0.034 & 1 & 56 & 0.854 \\
\hline
\end{tabular}

Dari tabel di atas, diperoleh hasil uji homogenitas yang menunjukkan bahwa hasil uji homogenitas setelah dilakukan perlakuan memperoleh signifikansi 0,856 dimana > 0,05 yang berarti bahwa kedua kelompok baik kelompok eksperimen maupun kelompok kontrol terdapat varian yang sama atau dikatakan homogen.

Tabel 10. Hasil analisis Uji T dengan independent sample T-tesr

\begin{tabular}{|c|c|c|c|c|c|c|c|c|c|c|}
\hline & \multicolumn{2}{|c|}{$\begin{array}{l}\text { Levene's Test } \\
\text { for Equality } \\
\text { of Variances }\end{array}$} & \multicolumn{7}{|c|}{ t-test for Equality of Means } \\
\hline & & \multirow[b]{2}{*}{$\mathrm{F}$} & \multirow[b]{2}{*}{ Sig. } & \multirow[b]{2}{*}{$\mathrm{t}$} & \multirow[b]{2}{*}{ Df } & \multirow{2}{*}{$\begin{array}{l}\text { Sig. } \\
(2- \\
\text { tailed } \\
\quad)\end{array}$} & \multirow{2}{*}{$\begin{array}{c}\text { Mean } \\
\text { Differenc } \\
\mathrm{e}\end{array}$} & \multirow{2}{*}{$\begin{array}{c}\text { Std. Error } \\
\text { Differenc } \\
\mathrm{e}\end{array}$} & \multicolumn{2}{|c|}{$\begin{array}{c}95 \% \\
\text { Confidence } \\
\text { Interval of the } \\
\text { Difference }\end{array}$} \\
\hline & & & & & & & & & $\begin{array}{c}\text { Lowe } \\
\mathrm{r}\end{array}$ & $\begin{array}{l}\text { Uppe } \\
\text { r }\end{array}$ \\
\hline \multirow{2}{*}{$\begin{array}{l}\text { Kemamp } \\
\text { uan } \\
\text { Berpikir } \\
\text { Kritis }\end{array}$} & $\begin{array}{l}\text { Equal } \\
\text { variances } \\
\text { assumed } \\
\end{array}$ & 0.033 & 0.856 & 5.081 & 56 & 0.000 & 5.917 & 1.165 & 3.584 & 8.250 \\
\hline & $\begin{array}{l}\text { Equal } \\
\text { variances } \\
\text { not assumed }\end{array}$ & & & 5.087 & 55.943 & 0.000 & 5.917 & 1.163 & 3.587 & 8.246 \\
\hline
\end{tabular}

Berdasarkan uji prasyarat dapat disimpulkan bahwa data berdistribusi normal. Selain itu, data prates dan posttest menunjukkan data yang homogen. Kemudian dilakukan analisis uji T menggunakan independent sample $\mathrm{T}$ test dengan hasil thitung sebesar 5,081 dengan signifikansi pada kolom sig. (2tailed) sebesar 0,000 dengan SPSS 25 for Windows. Penelitian ini membuktikan bahwa hasil uji beda rata-rata prates nilai kemampuan berpikir kritis siswa antara kelompok eksperimen yang diberikan perlakuan model pembelajaran Problem Posing lebih tinggi dibandingkan kelompok kontrol yang mendapatkan perlakuan model pembelajaran Problem Solving. Oleh karena itu, didapatkan hasil bahwa kelompok eksperimen lebih efektif dibandingkan dengan kelompok kontrol.

Selain itu, penelitian ini juga menggunakan uji N-Gain untuk melihat perbandingan dari kedua model pembelajaran Problem Solving dan Problem Posing. Hasil uji N-Gain baik kelompok eksperimen maupun kelompok kontrol dapat dilihat pada tabel dibawah ini:

Tabel 11. Hasil Uji N-Gain Kelas Eksperimen

\begin{tabular}{|c|c|c|c|c|c|c|c|c|}
\hline No & N-Gain & Kategori & No & N-Gain & Kategori & No & kategori & N-Gain \\
\hline 1 & 0.33 & Sedang & 11 & 0.63 & Sedang & 21 & Sedang & 0.34 \\
\hline 2 & 0 & Rendah & 12 & 0.36 & Sedang & 22 & Rendah & 0.05 \\
\hline
\end{tabular}


Perbandingan Model Pembelajaran Problem Solving dan Problem Posing Terhadap Kemampuan Berpikir Kritis Matematika Siswa Kelas V Sekolah Dasar, Prita Tiya Pramesti, Eunice Widyanti Setyaningtyas

\begin{tabular}{|c|c|c|c|c|c|c|c|c|}
3 & 0.11 & Rendah & 13 & 0.33 & Sedang & 23 & Sedang & 0.39 \\
\hline 4 & 0.57 & Sedang & 14 & 0.52 & Sedang & 24 & Rendah & 0.27 \\
\hline 5 & 0.18 & Rendah & 15 & 0.56 & Sedang & 25 & Rendah & 0.13 \\
\hline 6 & 0.53 & Sedang & 16 & 0.29 & Rendah & 26 & Sedang & 0.35 \\
\hline 7 & 0.31 & Sedang & 17 & 0.46 & Sedang & 27 & Sedang & 0.45 \\
\hline 8 & 0.04 & Rendah & 18 & 0.43 & Sedang & 28 & Sedang & 0.5 \\
\hline 9 & 0.42 & Sedang & 19 & 0.05 & Rendah & 29 & Rendah & 0.15 \\
\hline 10 & 0.65 & Sedang & 20 & 0.04 & Rendah & 30 & Rendah & 0.14 \\
\hline \multicolumn{7}{|l}{ Rata -rata } & & 0.31 \\
\end{tabular}

Tabel 12. Hasil Uji N-Gain Kelas Kontrol

\begin{tabular}{|c|c|c|c|c|c|c|c|c|}
\hline No & N-Gain & Kategori & No & N-Gain & Kategori & No & N-Gain & Kategori \\
\hline 1 & 0.23 & Rendah & 11 & 0.18 & Rendah & 20 & 0.07 & Rendah \\
\hline 2 & 0.23 & Rendah & 12 & 0.26 & Rendah & 21 & 0.43 & Sedang \\
\hline 3 & 0 & Rendah & 13 & 0.07 & Rendah & 22 & 0.13 & Rendah \\
\hline 4 & 0.19 & Rendah & 14 & 0.07 & Rendah & 23 & 0.53 & Sedang \\
\hline 5 & 0.04 & Rendah & 15 & 0 & Rendah & 24 & 0.08 & Rendah \\
\hline 6 & 0.03 & Rendah & 16 & 0.09 & Rendah & 25 & 0.41 & Sedang \\
\hline 7 & 0.38 & Sedang & 17 & 0.38 & Sedang & 26 & 0.19 & Rendah \\
\hline 8 & 0.28 & Rendah & 18 & 0.19 & Rendah & 27 & 0.43 & Sedang \\
\hline 9 & 0 & Rendah & 19 & 0.62 & Sedang & 28 & 0.55 & Sedang \\
\hline 10 & 0 & Rendah & \multicolumn{7}{|c|}{0.21} \\
\hline \multicolumn{7}{|c|}{ Rata-rata }
\end{tabular}

Rata-rata hasil uji N-Gain kelompok eksperimen dengan perlakuan menggunakan model Problem Posing menunjukkan perubahan peningkatan sebesar 0,31 dan dapat diartikan bahwa rata-rata kelompok eksperimen mengalami peningkatan kategori sedang. Sedangkan hasil rata-rata kelompok kontrol yang diberi perlakuan menggunakan model Problem Solving menunjukkan perubahan peningkatan sebesar 0,21 yang artinya rata-rata kelompok kontrol mengalami peningkatan kategori rendah. Berdasarkan hal tersebut menunjukkan bahwa kelompok eksperimen memiliki peningkatan yang lebih tinggi dibandingkan dengan kelompok kontrol.

\section{Pembahasan}

Penelitian ini menggunakan dua model pembelajaran berbasis masalah yaitu Problem Posing dan Problem Solving. Kedua model pembelajaran ini, terbukti dapat meningkatkan kemampuan berpikir kritis matematika siswa. Hal tersebut dapat dilihat dari beberapa aspek yang terdapat dalam berpikir kritis, yaitu: mengidentifikasi permasalahan, menentukan pertanyaan, strategi, mengumpulkan data, dan menyimpulkan. Kemudian dari aspek berpikir ktitis tersebut dapat dibuat indikator antara lain: mengidentifikasi permasalahan yang ada di dalam soal prates dan posttest, menentukan permasalahan yang terdapat dalam soal prates dan posttest, menentukan strategi yang dapat digunakan untuk memecahkan permasalahan yang terdapat dalam soal prates dan posttest, mengumpulkan data yang akan digunakan untuk melakukan pembuktian, menarik kesimpulan berdasarkan jawaban yang sudah 
diberikan. Indikator-indikator tersebut digunakan sebagai opsi jawaban dari soal prates maupun posttest.

Selain itu, dalam penelitian ini menggunakan prates terlebih dahulu untuk mengetahui kemampuan berpikir kritis awal siswa. Selajutnya diberikan perlakuan dengan menggunakan model pembelajaran Problem Posing pada kelas eksperimen dan Problem Solving pada kelas kontrol. Kemudian, diberikan posttest untuk mengetahui peningkatan kemampuan berpikir kritis pada siswa setelah diberi perlakuan khusus supaya dapat melihat adanya perbedaan nilai yang signifikan.

Berlandaskan hasil penelitian ini, dapat disimpulkan bahwa model pembelajaran Problem Posing lebih efektif untuk meningkatkan kemampuan berpikir kritis matematika siswa dibandingkan dengan model pembelajaran Problem Solving. Keberhasilan dalam meningkatkan kemampuan berpikir kritis matematika siswa kelas 5 dengan model pembelajaran Problem Posing dipengaruhi oleh kegiatan pembelajaran yang meminta siswa untuk membuat pertanyaan dan menjawabnya sendiri menggunakan cara yang telah ditentukan pada tahap sebelumnya. Berdasarkan hasil observasi yang dilakukan peneliti ketika melaksanakan penelitian menunjukkan bahwa siswa dapat berperan secara lebih aktif. Siswa mempu menjawab pertanyaan-pertanyaan yang diberikan dengan memahami permasalahannya terlebih dahulu kemudian merencanakan penyelesaian masalah sesuai dengan permasalahan yang dihadapinya dengan tepat. Selain itu, dengan membagi siswa ke dalam beberapa kelompok dapat memudahkan siswa untuk saling bertukar pikiran dan berdiskusi. Hasil penelitian ini menguatkan penelitian yang sama yang dilakukan oleh (Nugraha \& Mahmudi, 2015) menunjukkan bahwa metode pembelajaran berbasis masalah Problem Posing lebih unggul dibandingkan dengan pembelajaran konvensioanl, siswa yang diberikan pembelajaran dengan menggunakan model Problem Posing memberikan hasil yang lebih baik dibandingkan dengan siswa yang diberikan pembelajaran menggunakan pembelajaran konvensional. Artinya siswa yang diberikan pembelajaran dengan menggunakan model Problem Posing dapat meningkatakan kemampuan berpikir kritis secara signifikan dibandingkan dengan siswa yang yang diberikan pembelajaran menggunakan pembelajaran konvensional. Penelitian lain juga dilakukan oleh (Sarimanah, 2017) yang menunjukkan bahwa hasil N-gain kelas eksperimen lebih tinggi daripada kelas kontrol. Dapat diartikan bahwa terdapat peningkatan kemampuan berpikir kritis matematik pada kelas eksperimen jika dibandingkan dengan kelas kontrol.

\section{KESIMPULAN}

Berdasarkan hasil penelitian ini, dapat disimpulkan bahwa model pembelajaran Problem Posing lebih efektif dalam peningkatan kemampuan berpikir kritis matematika pada siswa dibandingkan dengan model pembelajaran Problem Solving. Hal tersebut dapat dibuktikan dengan melihat hasil rata-rata kelas eksperimen 80,6 yang diberikan perlakuan dengan menggunakan model pembelajaran Problem Posing yang mengalami peningkatan sedang dengan hasil N-Gain 0,3. Sedangkan model Problem Solving memperoleh nilai rata-rata lebih rendah dari Problem Posing yaitu 74,7 dengan nilai N-Gain 0,21. Oleh karena itu, hasil rata- rata dan nilai N-Gain menjelaskan bahwa model Problem Posing lebih efektif untuk peningkatan pembangunan kemampuan berpikir kritis matematika pada siswa kelas 5 
Perbandingan Model Pembelajaran Problem Solving dan Problem Posing Terhadap Kemampuan Berpikir Kritis Matematika Siswa Kelas V Sekolah Dasar, Prita Tiya Pramesti, Eunice Widyanti Setyaningtyas

dibandingkan dengan model Problem Solving. Oleh karena itu, model pembelajaran Problem Posing disarankan dapat diaplikasikan dan dikembangkan dalam proses pembelajaran di dalam kelas. Adapun tambahan saran bagi guru yaitu pemberian pengalaman baik secara teoretis maupun praktis tentang bagaimana membuat perangkat pembelajaran, melaksanakan pembelajaran, dan evaluasi proses pembelajaran dengan masing-masing model dalam mengembangkan kemampuan berpikir kritis matematika siswa.

\section{UCAPAN TERIMA KASIH}

Yang pertama penulis ucapkan terimakasih kepada Allah SWT yang telah memberikan kelancaran dalam menyelesaikan artikel ini. Yang kedua penulis mengucapkan terimakasih kepada kedua orang tua yang senantiasa mendoakan dan mendukung sehingga artikel ini bisa selesai. Yang ketiga penulis mengucapkan terimakasih kepada dosen pembimbing Eunice Widyanti Setyaningtyas, S.Pd., M.Pd. yang membimbing dan mengarahkan dalam proses penyelesaian artikel. Tidak lupa penulis mengucapkan terimakasih kepada teman-teman seperjuangan yang telah memberikan motivasi dan semangat tiada hentinya.

\section{REFERENSI}

Ardiyanti, Y. (2016). Berpikir Kritis Siswa Dalam Pembelajaran Berbasis Masalah Berbantuan Kunci Determinasi. JPI (Jurnal Pendidikan Indonesia), 5(2), 193. https://doi.org/10.23887/jpiundiksha.v5i2.8544

Djamarah, S. B., \& Zain, A. (1997). Strategi Belajar Mengajar. Jakarta: PT Rineka Cipta.

Fachrurazi. (2011). Penerapan Pembelajaran Berbasis Masalah Untuk Meningkatkan Kemampuan Berpikir Kritis Dan Komunikasi Matematis Siswa Sekolah Dasar. Jurnal Penelitian Pendidikan UPI, Edisi Khus(1), 76-89.

Kemendikbud. (2003). Undang Undang No 20 Tahun 2003. https://doi.org/10.16309/j.cnki.issn.10071776.2003.03.004

Kurniawan, H. (2016). Efektifitas Pembelajaran Problem Solving Terhadap Keterampilan Berpikir Kritis. Prosiding Seminar Matematika Dan Pendidikan Matematika, ISBN: 978-(November), 4756.

Nugraha, T. S., \& Mahmudi, A. (2015). Keefektifan Pembelajaran Berbasis Masalah Dan Problem Posing Ditinjau Dari Kemampuan Berpikir Logis Dan Kritis. Jurnal Riset Pendidikan Matematika, 2(1), 107. https://doi.org/10.21831/jrpm.v2i1.7154

Sanjaya, N. M. W. S. (2018). Pengaruh Metode Problem Solving dan Gaya Kognitif terhadap Kemampuan Analisis Siswa. Indonesian Journal Of Economics Education, 1(1), 1-8. https://doi.org/10.17509/jurnal

Sarimanah, T. (2017). Meningkatkan Kemampuan Berpikir Kritis Matematik Siswa Smp Melalui Pendekatan Problem Posing. Prisma, 6(2). https://doi.org/10.35194/jp.v6i2.123 
Sugiyono. (2011). Metode Penelitian Kuantitatif, Kualitatif dan R \& D. Bandung: Bandung.

Titin Sri Wartini1, Rita Retnowati2, E. S. 3. (2018). KEMAMPUAN BERPIKIR KRITIS SISWA

MENGGUNAKAN MODEL PROBLEM POSING DAN PROBLEM SOLVING PADA

MATERI SISTEM EKSKRESI. Journal of Science Education And Practice Volume, 2, 6723.

Widiawati, W., Subandi, S., \& Fajaroh, F. (2016). Pengaruh Problem Solving Berkelompok Terhadap Motivasi Belajar, Kemampuan Berpikir Kritis, Dan Hasil Belajar Siswa. Jurnal Ilmu Pendidikan Universitas Negeri Malang, 21(1), 104660. https://doi.org/10.17977/jip.v21i1.6493 